\title{
Impacts of wolves on rural economies from recreational small game hunting
}

\author{
Simen Pedersen ${ }^{1,2}$ (I) $\cdot$ Per Angelstam $^{2}$ (I) $\cdot$ Michael A.D. Ferguson $^{3} \cdot$ Petter Wabakken $^{1} \cdot$ Torstein Storaas $^{1}$
}

Received: 24 April 2018 / Revised: 13 August 2019 / Accepted: 5 September 2019 /Published online: 31 October 2019

(C) The Author(s) 2019

\begin{abstract}
Centralized management of large carnivore populations in rural and remote landscapes used by local people often leads to conflicts between the objectives of wildlife conservation and rural development. We tested the hypothesis that the presence of wolves indirectly reduces landowner revenues from traditional small game hunting, and that landowner revenues are more variable closer to wolf territories. The assumed mechanism is that hunters fear that their economically and culturally valuable hunting dogs may be killed by wolves, which results in reduced hunting, and thus reduced revenues for landowners where and when wolves occur. To determine the effect of wolf presence on revenues from sport hunting, we obtained data from 1990 to 2009 on income from small game management areas, in Hedmark and Oppland Counties in Norway, as well as locations of wolf territories. Small game management areas experienced increased sport hunting revenue with increasing distance to the closest wolf territory. Also, inter-annual variation in revenue decreased with increasing distance from wolf territories. Thus, wolf presence may reduce landowners' revenues from small game hunting, and cause higher economic variability in rural communities. It is important to note that while the economic impacts of wolves may be compensated where governments have the will and the economic resources, the impacts on the lifestyles of rural people (e.g. hunter's fear of losing prized dogs to wolves) will remain controversial.
\end{abstract}

Keywords Wolf conservation $\cdot$ Wolf-human conflicts $\cdot$ Dog $\cdot$ Wolf management $\cdot$ Compensations $\cdot$ Harvesting

\section{Introduction}

Management of large mammal populations where human communities use extensive rural or remote landscapes often leads to conflicts between the objectives of centralized

Electronic supplementary material The online version of this article (https://doi.org/10.1007/s10344-019-1319-x) contains supplementary material, which is available to authorized users.

Simen Pedersen

simen.pedersen@inn.no

1 Department of Forestry and Wildlife Management, Faculty of Applied Ecology, Agricultural Sciences and Biotechnology, Inland Norway University of Applied Sciences, Campus Evenstad, N-2480 Koppang, Norway

2 School for Forest Management, Faculty of Forest Sciences, Swedish University of Agricultural Sciences, PO Box 43, SE-739

21 Skinnskatteberg, Sweden

3 Qikiqtaaluk Wildlife Board, 3050 Huntingdon Court, Unit A, Gloucester, ON K1T 2R1, Canada wildlife conservation and localized rural development (e.g. Woodroffe et al. 2005). Worldwide, large mammal populations may cause direct risks to humans themselves, losses of valued domestic animals and crops, change traditional patterns of human land use and inflame differences in cultural values among communities (Fritts et al. 2003; Kolowski and Holekamp 2006; Liberg et al. 2010; Muhly and Musiani 2009; Treves and Karanth 2003). All these challenges are often complicated by centralized political decisions for large mammal and biodiversity conservation in areas viewed as wilderness, which, however, are traditionally and actively used in multiple ways by rural and indigenous people (Masse 2016).

On one hand, large carnivores such as wolves (Canis lupus) constitute an important component of Holarctic environments, where they influence both other species and ecosystem functions. Wolves may limit large herbivore populations through predation, and limit populations of mesopredators (e.g. red fox Vulpes vulpes), through intraguild predation (Ripple et al. 2014a). Trophic cascades apparently caused by the impacts of wolves on cervid densities (Ripple and Beschta 2012a) have been argued to 
consequentially affect small mammals (Miller et al. 2012), songbirds (Baril et al. 2011), regeneration of trees (Ripple and Beschta 2012b), berry production (Ripple et al. 2014b) and even stream morphology (Beschta and Ripple 2012). On the other hand, it can be argued that trophic interactions are more complex, and that wolf-induced trophic cascades may not be widespread, and maybe only an effect traceable in the Yellowstone ecosystem (Allen et al. 2017a; Kuijper et al. 2016; Mech 2012; Mech 2017; Peterson et al. 2014). To cite Mech (2012) "The wolf is neither a saint nor a sinner except to those who want to make it so".

The conservation of large carnivores including wolves is particularly challenging to manage (Mech 1995) and is an example of a" wicked problem", one that is difficult or impossible to resolve because of contradictory stakeholder views, incomplete knowledge and complex mechanisms (Duit and Löf 2015; Enserink and Vogel 2006; Jacobsen and Linnell 2016). The return and recovery of wolf populations in Scandinavia is a prime example where the wolf's ecological needs for suitable habitat and prey may be satisfied (Liberg et al. 2010; Wabakken et al. 2001). However, people's views about the presence of wolves remain controversial, especially in rural settings (Ericsson and Heberlein 2003; Karlsson and Sjostrom 2008; Skogen et al. 2018; Skogen and Krange 2003). In Norway, recovery of a viable population of wolves have been politically decided at the international and national levels, but need to be put into force and tolerated regionally and locally on privately owned property in rural and remote areas (Jacobsen and Linnell 2016). Where wolves occur, the most commonly documented type of economic loss has been depredation of livestock, including semi-domestic ungulates (Bostedt and Grahn 2008; Kolowski and Holekamp 2006; Muhly and Musiani 2009; Wabakken et al. 2017). For rural landowners in Norway, hunting big and small game may be important to their annual income, as many lease hunting rights to hunters. Hunting dogs for big and small game are widely used in Norway, and as such dogs are both culturally and economically valuable. Wolf presence may negatively affect rural revenues, if it deters hunters because of the risk of wolf attacks on their dogs (Kojola and Kuittinen 2002; Lescureux and Linnell 2014). Thereby, decreased interest among hunters in using lands within or close to wolf territories could consequentially lead to reduced revenues for landowners whose lands are within or near wolf territories (Angelstam et al. 2013; Storaas et al. 2008). Noteworthy, the presumed effect of wolf presence on revenue to landowners from leasing small game hunting rights is not a direct effect of wolf predation on small game, but rather an indirect effect caused by the risk and fear among hunters to lose their economic and socially valuable dogs to wolves.

Hunting has economic, social, cultural and ecological functions for humans (Fischer et al. 2013). Here, we focus on the economic function of hunting in rural and remote landscapes where hunting is a traditional and culturally important land use. The aim of this study is to assess the impact of wolf presence on hunting revenues for small game management areas in relation to distance from Scandinavian wolf territories. We employ a distance gradient from small game management areas overlapping wolf territories to small game management areas far away from wolf territories. We tested if the proximity of wolves reduces revenue from small game hunting. We compare how economic revenue changed with spatial and temporal variation in wolf presence over a 20 -year period in south-eastern Norway. To our knowledge, this is the first study of potential impacts of wolves on rural economy through small game hunting.

\section{Methods}

\section{Study area}

Our study area is located at the north-western edge of the Scandinavian wolf population range of resident breeding pairs and packs in south-eastern Norway, and includes Hedmark and Oppland counties (Fig. 1, 61 ${ }^{\circ} \mathrm{N}, 11^{\circ} \mathrm{E}$ ) in the northern and middle boreal zones (Moen et al. 1999). Hedmark County borders Sweden to the west, where the majority of the Scandinavian wolf population occurs (Wabakken et al. 2001; Wabakken et al. 2016), while Oppland County is located further west and outside the wolf breeding range (Fig. 1). During the winter 2015-16, the Scandinavian wolf population included 56 Swedish packs or pairs, and 14 Norwegian packs or pairs, of which 10 were found partly or fully within Hedmark County, while none were in Oppland County (Wabakken et al. 2016). During the past 30 years, the majority of Norwegian resident wolves have been found in Hedmark County (https://www.skandulv.nina.no). The Norwegian wolf population also consists of non-resident wolves (mainly dispersing 1-year-old pups) that may pass through or occupy an area for some time before continuing dispersing or becoming a resident wolf.

We focused on small game management areas along an east-west "wolf" gradient in Hedmark and Oppland Counties, from areas to the east where resident wolves occurred in Hedmark County (Fig. 1), and areas to the west in Oppland County far from wolf territories. Every winter for the past 40 years, the Scandinavian wolf population has been monitored and the territory and territory centre points of each pack and pair have been located, mapped and distinguished from other territories. This has been done by a combination of snow-tracking (including recording of territory scent-marking), DNA- and pedigree analyses, and in some cases, GPS- and radio-telemetry (available from annual Scandinavian wolf status reports [e.g. Wabakken et al. 2001; Wabakken et al. 2016]). Each wolf territory's history, through establishment, annual reproduction and cause 


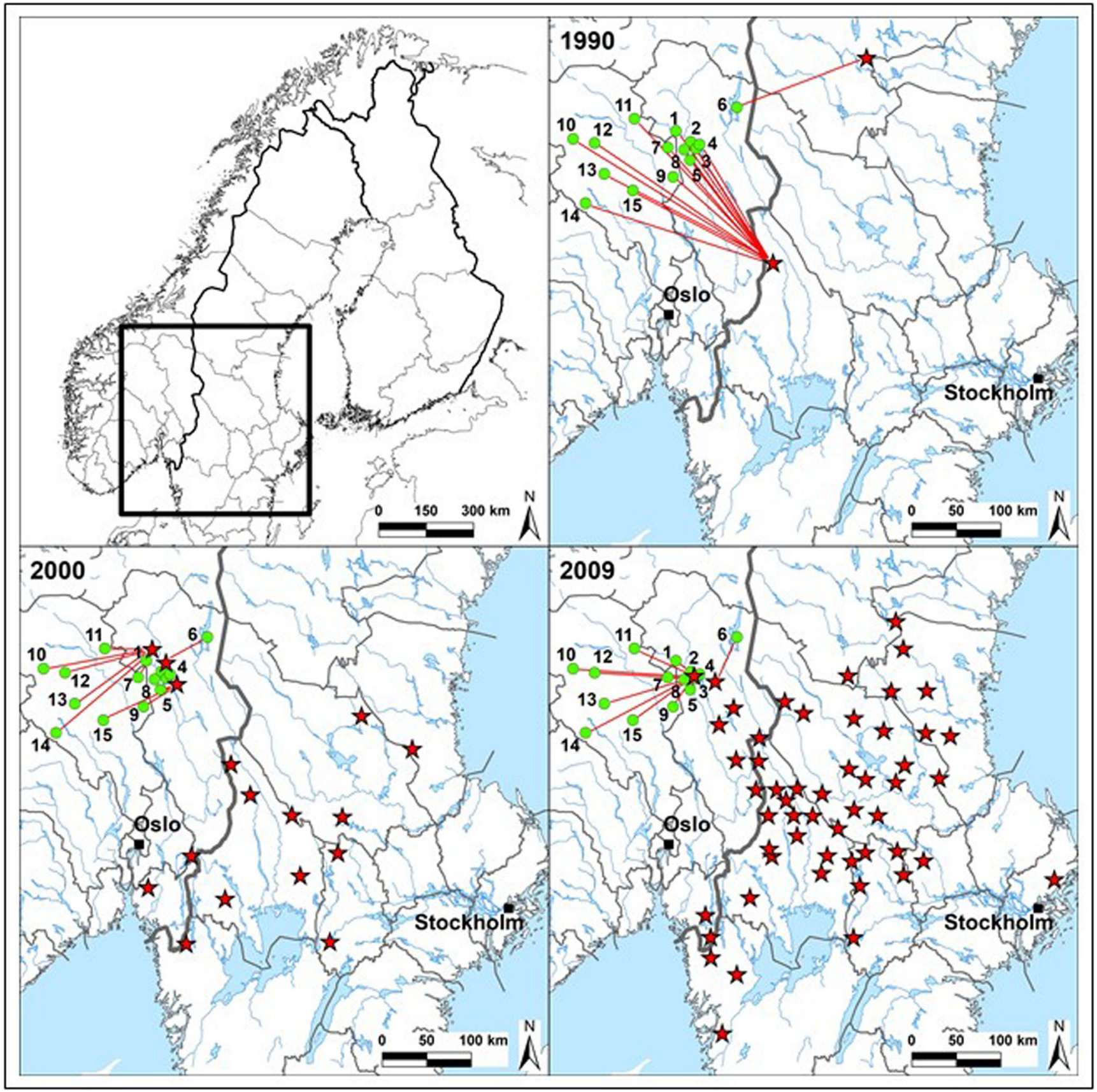

Fig. 1 Study area, containing the 15 small game management areas (green dots) in Oppland (to the west) and Hedmark (to the east) Counties in Norway. Red stars represent centre points for Scandinavian wolf pack and pair territories. Red lines represent the calculated distance from each small game management area to the closest wolf territory. The three maps of the situation in 1990, 2000 and 2009 exemplify the development of the Scandinavian wolf population over the last decades and how wolf presence gradually have increased during this time. Details of small game management areas numbered from 1 to 15 may be found in Online Resource 1. Thin grey lines represent county borders, while thick grey line represents the Swedish-Norwegian border

\section{Norwegian hunting system}

Scandinavian wolf status reports (e.g. Wabakken et al. 2016). Modelled probabilities of future wolf territory occurrence were similar in Hedmark and Oppland counties if wolves were allowed to expand freely (Karlsson et al. 2007); thus, the whole study area should be homogenous in terms of possible wolf habitat.
In Norway, as a general rule, nobody owns wildlife; however, the landowner has the right to hunt, and may lease this right to others. It is common for landowners to organize themselves in local game management areas. Game management areas may be held by individual private landowners, landowner 
associations or the federal state (Online Resource 1). Landowners may charge small game hunters to access their lands by selling exclusive hunting permits to single hunters or small groups of hunters. Alternatively, they sell hunting licences on the open market with few or no restriction on the total number of hunters in the area. In Norway, $4 \%$ of the people are hunters, while hunters make up $7 \%$ and $5 \%$ of residents of Hedmark and Oppland counties, respectively (data from Statistics Norway, https://www.ssb.no). In general, most Norwegians are supportive towards hunting and hunters (TNS Gallup 2017), partly because it is an activity carried out by all layers of the society.

Small game hunting using dogs is carried out mainly by pointing dogs for forest grouse (Tetrao urogallus, Lyrurus tetrix) and willow ptarmigan (Lagopus lagopus), as well as barking dogs either for chasing the quarry (mountain hare (Lepus timidus) or treeing the quarry (forest grouse). In the period from 1995 to January 2019, a total of 146 dogs were classified as 'documented' or 'presumed' killed or wounded by wolves in Norway, (https://www.rovbase.no). The dog breeds most frequently attacked by wolves were barking dogs, utilized to hunt mountain hares (Lepus timidus) and moose (Alces alces) (Odden et al. 2018).

\section{Data collection and statistical analysis}

To assess effects of wolf presence on landowner revenues from small game hunting, we contacted responsible managers of small game hunting areas to obtain data on revenues for the years 1990-2009 (Online Resource 1). We obtained revenue data from individual landowners, landowner associations and state land. Data from this 20 -year period enabled us to assess spatial and temporal landowner revenues in relation to distance from wolf territory (Fig. 1). Some small game management areas were unwilling to provide data, while some data were incomplete due to landownership changes. In total, we obtained useful revenue data from 15 small game management areas (Fig. 1, Online Resource 1). The dataset analysed during the current study are available in the Open Science Framework repository (https://osf.io/rnw57/). To ensure a consistent sample of small game management areas, we did not include data from the years after 2009 because several land consolidation processes within the study area affected the ownership structure and thereby how revenues were documented.

To test the hypothesis that the presence of wolves indirectly affects landowners' revenues from small game hunting, for each year from 1990 to 2009 , we calculated the distance in kilometers from the centre of each small game management area to the centre of the closest wolf territory (Online Resource 1). Preliminary analysis revealed that low distance values, e.g. $<30 \mathrm{~km}$ would imply that the small game management area is largely overlapped by a wolf territory (Online Resource 1).
Monitoring precision has generally increased over the years (from snow-tracking in the early years to GPS-collaring with frequent positioning in the later years), and thus estimated territory size. Therefore, we chose to calculate centerpointto-centerpoint distance rather than border-to-border distance.

To control for inflation, annual revenues were corrected using the Norwegian consumer price index (https://www.ssb.no/kpi). Landowners managed their lands for small game hunting to varying degrees, depending on their incomes from other resources and economic activities. Also, how revenue was reported in relation to area may have varied. As a result, revenues per square kilometer varied up to ten-fold among the 15 small game management areas (Online Resource 1); nevertheless, we were most interested in the relative annual variation among all landowners in each year (t). Consequently, we calculated a relative revenue, based on revenue for each year (revenue $t$ ) standardized against the landowner's maximum revenue for all years (revenue $t_{\max }$ ), and used this as our response variable:

Relative revenue : $\frac{\text { Revenue } t}{\text { Revenue } t_{\max }}$

First, we tested for an effect of distance from nearest wolf territory on revenues from small game hunting. Here, we first tried to fit mixed-effects beta regression models (from the glmmTMB package in $\mathrm{R}$ [Magnusson et al. 2019]) to account for data being ratios bounded by 0 and 1 and to account for dependencies within each small game management area. Although this model yielded results, it failed to converge properly, indicating a lack of model fit to the data. Thus, we fitted a simpler linear mixed-effects model (from the nlme package in R [Pinheiro et al. 2012]) with revenue ratio as the response variable and distance to wolf territory as explanatory variable, and small game management area as a random term to avoid pseudoreplication. Second, to test for a spatial effect of wolves on revenues from small game hunting, we determined the coefficient of variation $(\mathrm{CV})$ in revenue for each small game management area. We used the $\mathrm{CV}$ for each small game management area as the response variable and fitted a linear model with distance from wolf territory as continuous explanatory variable. All analyses reported in this paper were performed using R version 3.5.2 (R Development Core Team 2018).

\section{Results}

Small game management areas experienced reduced revenue at times and places when wolf territories were close. Revenue from small game management areas increased with increasing distance from the nearest wolf territory $(t=6.91, \mathrm{df}=239$, $p<0.001$, Fig. 2). Then, we tested for an effect of distance from occupied wolf territories on inter-annual variation in 
Fig. 2 Relation between distance to nearest wolf territory and revenue index (proportion of revenue a given year referenced to the year with the highest revenue) from small game hunting $( \pm 95 \%$ CI). Data from 15 small game management areas over the years 1990-2009

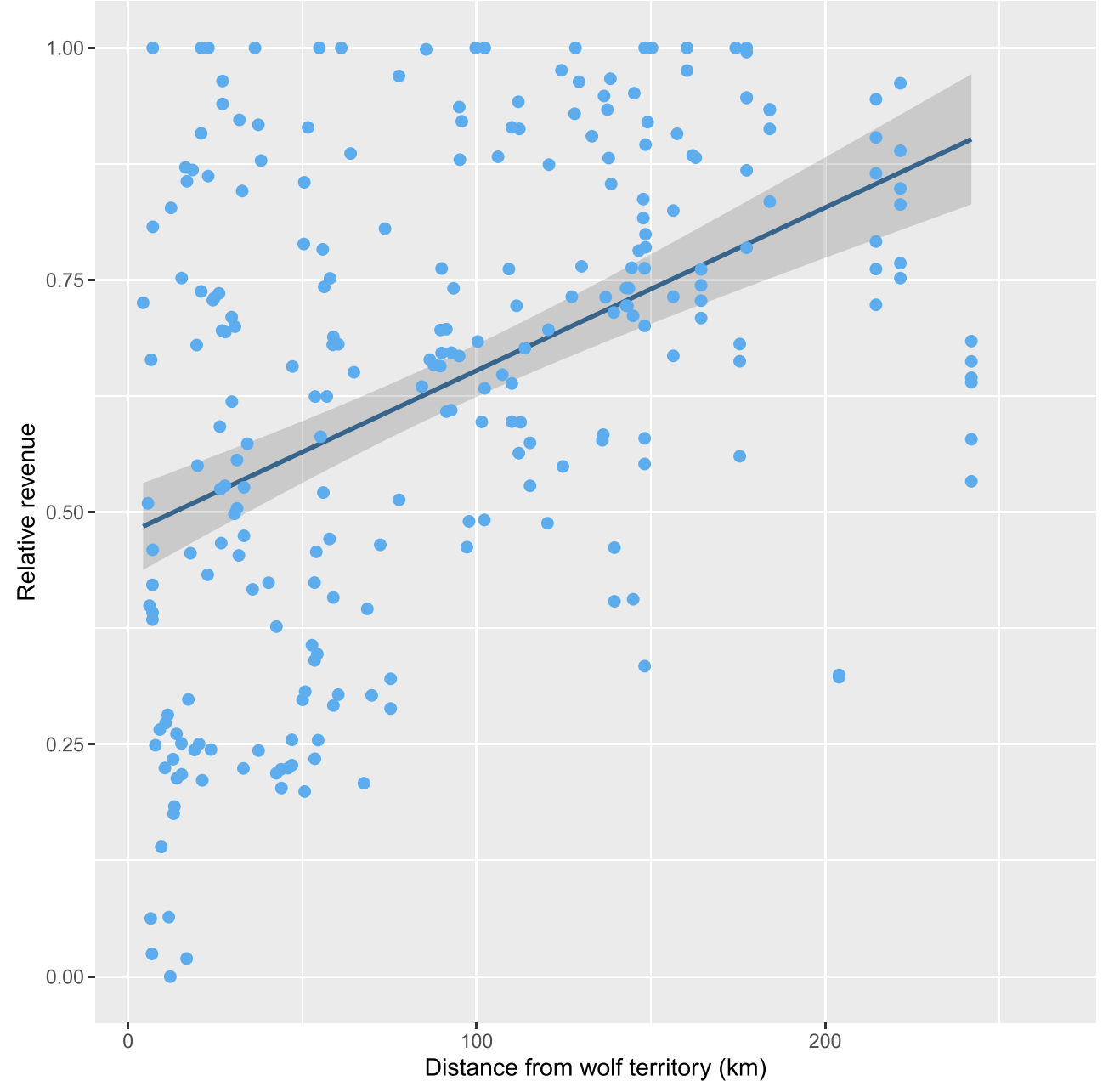

revenue for all small game management areas. Here, we found a decrease in the coefficient of variation $(\mathrm{CV})$ with increasing distance from wolf territory borders $(t=-3.60, \mathrm{df}=13, p=$ 0.003 , Fig. 3). This indicates large inter-annual variation in revenue within and close to wolf territories with less variation far from wolf territories.

\section{Discussion}

In our study area, wolf proximity affected small game management areas which leased small game hunting rights in two ways by (1) reducing revenue, and (2) increasing the interannual variability of revenue.

In the current small game hunting system, economic losses due to wolves were apparently caused by the perceived risk and fear from hunters of losing their dogs while hunting, making areas with or near wolves less attractive as hunting areas. In Norway, much small game hunting is announced though the website https://www.inatur.no. Here, 53 out of 256 (21\%) of advertisements for small game hunting in Hedmark County mention the Norwegian word for wolf. Advertisements on www.inatur.no were either warning about the risk of wolves in the given areas (29 out of the 53), or pointing out as a selling argument about no wolves in the given areas (17 out of 53). Seven of the advertisements could not easily be classified as warnings or selling arguments (https://www.inatur.no, accessed December 19th 2017). For Oppland, only 2 out of 104 advertisements mentions wolves, neither of these two could easily be classified as selling or warning arguments. The mean frequency of occurrence of the word "wolf" in advertisements for small game hunting for the rest of Norway excluding Hedmark and Oppland is only 6 out of 658 advertisements (1\%). This indicates that wolves are indeed perceived as a threat to the dogs of small game hunters and as a revenue risk for landowners selling small game hunting rights in Hedmark.

Small game hunting is an important source of economic income in rural areas (Fischer et al. 2013), both directly for the landowners and indirectly in the local community through the socio-economic value creation for local rural businesses. We suspect the presence of wolves may make landowners less willing to invest in business development.

For hunters, the social and cultural functions (Fischer et al. 2013) of hunting may be affected by expanding wolf 
Fig. 3 Distance from centre of small game management area to the centre of the closest wolf territory plotted against the coefficient of variation $(\mathrm{CV})$ in revenue (years 1990-2009) from small game hunting $( \pm 95 \% \mathrm{CI})$

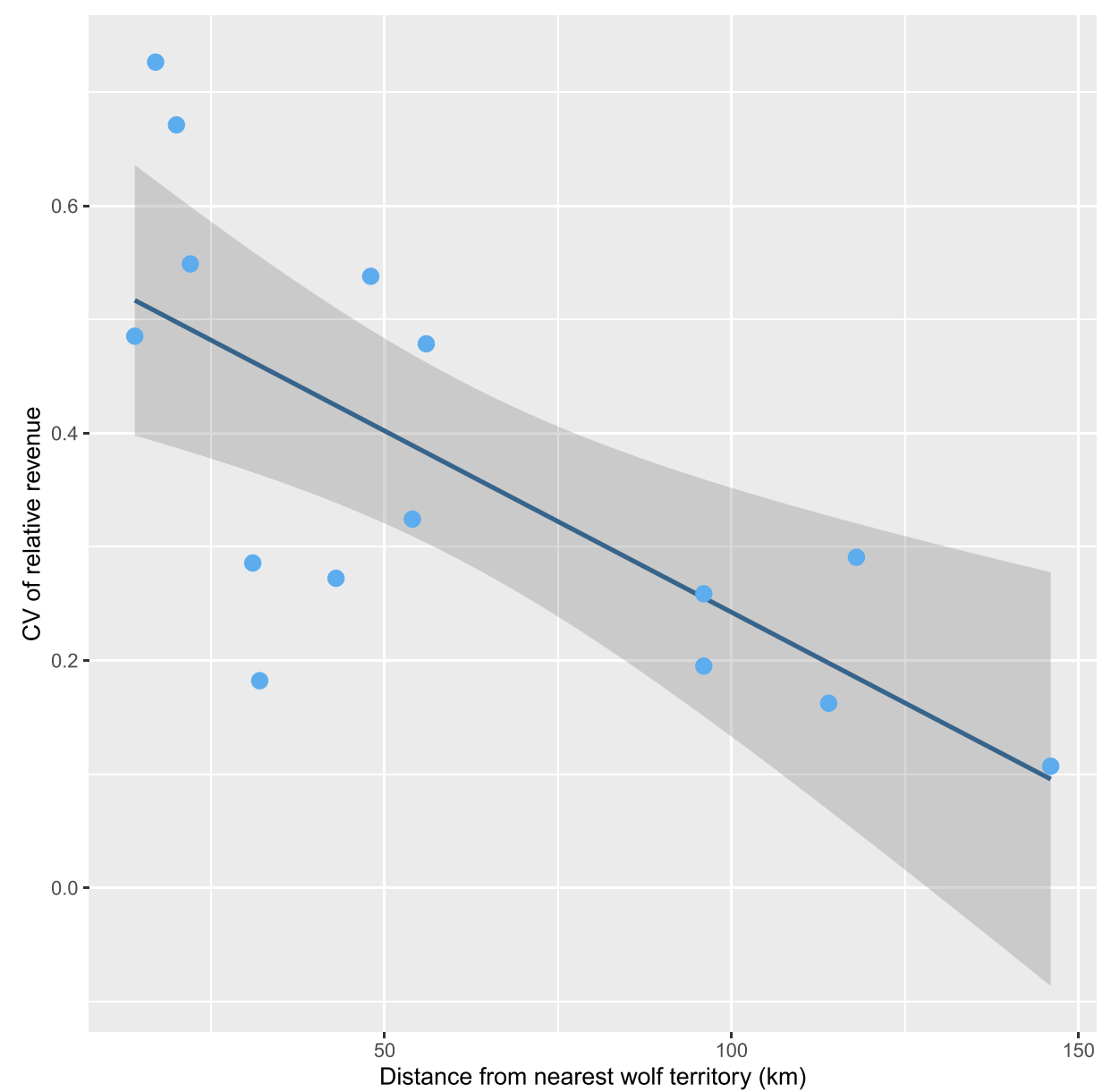

presence. Hunters have several alternatives, including to (1) stop hunting in the areas where they have been used to hunting, (2) modify their traditional methods of hunting with dogs to adapt to the presence of wolves or (3) to risk wolves killing their dogs and continue their traditional methods in their traditional areas, either with (Karlsson 2009; Karlsson 2014) or without wolf protection gear for their dogs. Hunting using specialized breeds of dogs is a deeply rooted cultural tradition in Norway (see e.g. Barth 1891; Pay 1938). Small game hunting is thus not only about harvesting a resource for food, but also about experiencing nature in traditional or ancestral ways, maintaining long-term relationships with fellow hunters and nurturing year-round relationships with hunting dogs.

As in many parts of the world, governance and management of the wolf in Scandinavia is a balancing act and challenge (Mech 1995) which often pits centralized policy makers against local rural people faced with the implementation of the policies (Broberg and Brannlund 2008; Duit and Löf 2015; Enserink and Vogel 2006; Ericsson and Heberlein 2003; Heberlein and Ericsson 2008; Jacobsen and Linnell 2016; Karlsson and Sjostrom 2008; Skogen et al. 2018; Skogen and Krange 2003). The controversy revolves around several issues. Karlsson and Sjostrom (2008) found that the main arguments opposing wolf conservation are predation risks on hunting dogs, livestock and semi-domesticated reindeer (Rangifer tarandus). In this rural-urban context, Skogen and Krange (2003) argue that the conflict is not about the wolf per se, but rather the wolf and its conservation as a symbol of the urban dominance over rural communities.

Wolves may contribute by adding one more species, a charismatic top predator, to the ecosystems. The trophic effects of wolves are debatable (Allen et al. 2017a; Allen et al. 2017b; Bruskotter et al. 2017; Kuijper et al. 2016; Mech 2012; Mech 2017; Peterson et al. 2014); however, it has been argued that if sufficiently abundant in the long term, wolves could lead to several potential cascading ecosystem effects on the recruitment of deciduous trees of importance for biodiversity conservation (Angelstam et al. 2017; Angelstam et al. 2000; Beschta and Ripple 2009), damages to economically important tree species (Angelstam et al. 2017) and changing mesopredator populations (e.g. red fox (Vulpes vulpes), pine marten (Martes martes) (Elmhagen et al. 2010; Ripple et al. 
2014b). Meanwhile, increasing wolf populations may increase depredation on domestic or semi-domestic livestock, create fear of losing hunting dogs, and as the current study shows, reduce landowner revenues from leasing small game hunting rights.

To mitigate this wicked problem, several approaches have been tried. The Scandinavian wolf population is carefully monitored and many individual wolves are marked and equipped with GPS collars. The Scandinavian Wolf Project (SKANDULV) together with Norwegian and Swedish hunters associations established the "wolf-telephone", later replaced by the "wolf-web". Here, hunters may get updated approximate location with a $10 \times 10 \mathrm{~km}$ resolution of the latest GPS-position from collared wolves, which thereby may reduce the risk of their dogs being killed by wolves (http://webmap.slu.se/website/vargwebb/ viewer.asp, accessed September 12th 2013, Brainerd 2003). In addition, a "wolf zone" has been created in Norway, where abundance of domestic sheep and other livestock is almost non-existent, and where wolves are allowed to establish breeding packs (Wabakken et al. 2017). However, on a local or regional scale, this zoning system may not be working, since poaching of wolves is viewed as just as acceptable inside as outside the wolf zone (Gangaas et al. 2013). In 2001, the Directorate for Nature Management leased the hunting rights from some landowners in Stor-Elvdal municipality, Hedmark, affected by wolves as a compensation for their loss of hunting opportunities. Although the lease was much lower than the expected economic losses, the landowners felt their challenges were taken seriously (Angelstam et al. 2013; Storaas et al. 2008). The wolf conflict may be reduced if landowners are compensated for the economic loss of hosting wolves (Angelstam et al. 2013; Storaas et al. 2008). Indeed, in 2017, the Norwegian government decided that municipalities hosting wolves may apply for funding on an annual basis to compensate or mitigate the consequences of having wolves within the municipality borders (MCE 2017). Given that wolves exert a mesopredator pressure (Elmhagen et al. 2010; Ripple et al. 2014b), this with time may cause higher abundances of small game species. Landowners in areas with wolves could also be compensated by allowing winter hunting (after December 31st) for forest grouse such as capercaillie and black grouse, allowing them to market this new hunting opportunity.

Acknowledging the economic and social consequences of hosting wolves may be important for successful wolf conservation. Rural economies are dependent on many small, interconnected sources of revenue, as well as deep-rooted traditions and social capital that influence the functioning and sustainability of rural communities. Nevertheless, it is important to note that while the economic impacts of wolves may be compensated where governments have the will and the economic resources, the impacts on the lifestyles of rural people (e.g. hunter's fear of losing prized dogs to wolves) will remain controversial.

Acknowledgements We thank all landowners, landowner associations, municipal and state forests for providing data on revenue from small game hunting. Jørn Grønbekk, Erling Maartmann, Ole-Knut Steinset, and Thomas H. Strømseth supported our study by extensive fieldwork, and determined the wolf territory boundaries each winter. Dan Parker, Robert Axelsson, Marine Elbakidze, Barbara Zimmermann and Ståle Nordgård provided useful input on previous versions of the draft and during coffee cup discussions. Erling Maartmann assisted with maps.

Funding information We acknowledge funding from Skogtiltaksfondet (D-2017-23) to S Pedersen and The Swedish Research Council for Environment, Agricultural Sciences and Spatial Planning (2011-1737) to P Angelstam as principal investigator, as well as a R\&D grant from Hedmark University College to MAD Ferguson.

Compliance with ethical standards Permission to publish the revenue data were obtained from the respective small game management areas. This article does not contain any studies with human participants or animals performed by any of the authors.

Conflict of interest The authors declare that they have no conflict of interest.

Open Access This article is distributed under the terms of the Creative Commons Attribution 4.0 International License (http:// creativecommons.org/licenses/by/4.0/), which permits unrestricted use, distribution, and reproduction in any medium, provided you give appropriate credit to the original author(s) and the source, provide a link to the Creative Commons license, and indicate if changes were made.

\section{References}

Allen BL, Allen LR, Andrén H, Ballard G, Boitani L, Engeman RM, Fleming PJS, Ford AT, Haswell PM, Kowalczyk R, Linnell JDC, Mech LD, Parker DM (2017a) Can we save large carnivores without loosing carnivore science? Food webs 12:64-75. https://doi.org/10. 1016/j.fooweb.2017.02.008

Allen BL, Allen LR, Andrén H, Ballard G, Boitani L, Engeman RM, Fleming PJS, Ford AT, Haswell PM, Kowalczyk R, Linnell JDC, Mech LD, Parker DM (2017b) Large carnivore science: nonexperimental studies are useful, but experiments are better. Food webs 13:49-50. https://doi.org/10.1016/j.fooweb.2017.06.002

Angelstam P, Wikberg P-E, Danilov P, Faber WE, Nygrén K (2000) Effects of moose density on timber quality and biodiversity restoration in Sweden, Finland, and Russian Karelia. Alces 36:133-145

Angelstam P et al (2013) Solving problems in social-ecological systems: definition, practice and barriers of transdisciplinary research. Ambio 42:254-265. https://doi.org/10.1007/s13280-012-0372-4

Angelstam P, Manton M, Pedersen S, Elbakidze M (2017) Disrupted trophic interactions affect recruitment of boreal deciduous and coniferous trees in northern Europe. Ecol Appl 27:1108-1123. https:// doi.org/10.1002/eap.1506

Baril LM, Hansen AJ, Renkin R, Lawrence R (2011) Songbird response to increased willow (Salix spp.) growth in Yellowstone's northern range. Ecol Appl 21:2283-2296. https://doi.org/10.1890/10-0169.1

Barth JB (1891) Experiences from hunting small game in Norway. H. Aschehoug og Co Forlag, Kristiania (In Norwegian) 
Beschta RL, Ripple WJ (2009) Large predators and trophic cascades in terrestrial ecosystems of the western United States. Biol Conserv 142:2401-2414. https://doi.org/10.1016/j.biocon.2009.06.015

Beschta RL, Ripple WJ (2012) The role of large predators in maintaining riparian plant communities and river morphology. Geomorphology 157:88-98. https://doi.org/10.1016/j.geomorph.2011.04.042

Bostedt G, Grahn P (2008) Estimating cost functions for the four large carnivores in Sweden. Ecol Econ 68:517-524. https://doi.org/10. 1016/j.ecolecon.2008.05.008

Brainerd SM (2003) Conflict reducing measures in carnivore management. NINA Report 66 (In Norwegian with english summary)

Broberg T, Brannlund R (2008) On the value of large predators in Sweden: a regional stratified contingent valuation analysis. J Environ Manag 88:1066-1077. https://doi.org/10.1016/j.jenvman. 2007.05.016

Bruskotter JT, Vucetich JA, Smith DW, Nelson MP, Karns GR, Peterson RO (2017) The role of science in understanding (and saving) large carnivores: a response to Allen and colleagues. Food webs 13:4648. https://doi.org/10.1016/j.fooweb.2017.05.004

Duit A, Löf A (2015) Dealing with a wicked problem? A dark tale of carnivore management in Sweden 2007-2011. Adm Soc 50:10721096. https://doi.org/10.1177/0095399715595668

Elmhagen B, Ludwig G, Rushton SP, Helle P, Linden H (2010) Top predators, mesopredators and their prey: interference ecosystems along bioclimatic productivity gradients. J Anim Ecol 79:785-794. https://doi.org/10.1111/j.1365-2656.2010.01678.x

Enserink M, Vogel G (2006) The carnivore comeback. Science 314:746749. https://doi.org/10.1126/science.314.5800.746

Ericsson G, Heberlein TA (2003) Attitudes of hunters, locals, and the general public in Sweden now that the wolves are back. Biol Conserv 111:149-159 doi:Pii S0006-3207(02)00258-6

Fischer A, Sandström C, Delibes-Mateos M, Arroyo B, Tadie D, Randall D, Hailu F, Lowassa A, Msuha M, Kereži V, Reljić S, Linnell J, Majić A (2013) On the multifunctionality of hunting an institutional analysis of eight cases from Europe and Africa. J Environ Plan Manag 56:531-552. https://doi.org/10.1080/09640568.2012. 689615

Fritts SH, Stephenson RO, Hayes RD, Boitani L (2003) Wolves and humans. In: Mech LD, Boitani L (eds) Wolves: behaviour, ecology and conservation. University of Chigaco Press, Chicago, pp 289316

Gangaas KE, Kaltenborn BP, Andreassen HP (2013) Geo-spatial aspects of acceptance of illegal hunting of large carnivores in Scandinavia. PLoS One 8:e68849. https://doi.org/10.1371/journal.pone.0068849

Heberlein TA, Ericsson G (2008) Public attitudes and the future of wolves Canis lupus in Sweden. Wildl Biol 14:391-394. https://doi.org/10. 2981/0909-6396(2008)14[391:PAATFO]2.0.CO;2

Jacobsen KS, Linnell JDC (2016) Perceptions of environmental justice and the conflict surrounding large carnivore management in Norway-implications for conflict management. Biol Conserv 203:197-206. https://doi.org/10.1016/j.biocon.2016.08.041

Karlsson J (2009) First testing of protective vest from protector to avoid wolf attacks on huntingdogs. Viltskadecenter Report 2009-1, Riddarhyttan, (In Swedish)

Karlsson J (2014) First testing of electric vest from Wolfproofexperiences from 10 dogs and 200 huntingdays. Viltskadecenter Report 2014-2, Riddarhyttan, (In Swedish)

Karlsson J, Sjostrom M (2008) Direct use values and passive use values: implications for conservation of large carnivores. Biodivers Conserv 17:883-891. https://doi.org/10.1007/s10531-008-9334-3

Karlsson J, Brøseth H, Sand H, Andrén H (2007) Predicting occurrence of wolf territories in Scandinavia. J Zool 272:276-283. https://doi. org/10.1111/j.1469-7998.2006.00267.x

Kojola I, Kuittinen J (2002) Wolf attacks on dogs in Finland. Wildl Soc Bull 30:498-501. https://doi.org/10.2307/3784509
Kolowski JM, Holekamp KE (2006) Spatial, temporal, and physical characteristics of livestock depredations by large carnivores along a Kenyan reserve border. Biol Conserv 128:529-541. https://doi.org/ 10.1016/j.biocon.2005.10.021

Kuijper DPJ, Sahlen E, Elmhagen B, Chamaille-Jammes S, Sand H, Lone K, Cromsigt JPGM (2016) Paws without claws? Ecological effects of large carnivores in anthropogenic landscapes. Proceedings of the Royal Society B-Biological Sciences 283. https://doi.org/10.1098/ rspb.2016.1625

Lescureux N, Linnell JDC (2014) Warring brothers: the complex interactions between wolves (Canis lupus) and dogs (Canis familiaris) in a conservation context. Biol Conserv 171:232-245. https://doi.org/10. 1016/j.biocon.2014.01.032

Liberg O, Aronson A, Brainerd SM, Karlsson J, Pedersen HC, Sand H, Wabakken P (2010) Integrating research into management of a recolonizing wolf population - the Scandinavian model. In: Musiani M, Boitani L, Paquet P (eds) The world of wolves: new perspectives on ecology, behaviour and policy. University of Calgary Press, Calgary

Magnusson A, Skaug H, Nielsen A, Berg C, Kristensen K, Maechler M, van Bentham K, Sadat N, Bolker B, Brooks M (2019) glmmTMB: generalized linear mixed models using template model builder, $\mathrm{R}$ package version 0.2.3

Masse F (2016) The political ecology of human-wildlife conflict: producing wilderness, insecurity, and displacement in the Limpopo National Park. Conserv Soc 14:100-111. https://doi.org/10.4103/ 0972-4923.186331

MCE (2017) Tilskuddsregelverk knyttet til kapittel 1420 post 65 - Regler om tilskudd til kommuner med ulverevir i Hedmark, Akershus og Østfold. Ministry of Climate and Environment, Norwegian Government (In Norwegian)

Mech LD (1995) The challenge and opportunity of recovering wolf populations. Conserv Biol 9:270-278. https://doi.org/10.1046/j.15231739.1995.9020270.x

Mech LD (2012) Is science in danger of sanctifying the wolf? Biol Conserv 150:143-149. https://doi.org/10.1016/j.biocon.2012.03. 003

Mech LD (2017) Where can wolves live and how can we live with them? Biol Conserv 210:310-317. https://doi.org/10.1016/j.biocon.2017. 04.029

Miller BJ, Harlow HJ, Harlow TS, Biggins D, Ripple WJ (2012) Trophic cascades linking wolves (Canis lupus), coyotes (Canis latrans), and small mammals. Canadian Journal of Zoology-Revue Canadienne De Zoologie 90:70-78. https://doi.org/10.1139/z11-115

Moen A, Lillethun A, Odland A (1999) National atlas of Norway: vegetation. Norwegian Mapping Authority, Hønefoss, Norway

Muhly TB, Musiani M (2009) Livestock depredation by wolves and the ranching economy in the Northwestern US. Ecol Econ 68:24392450. https://doi.org/10.1016/j.ecolecon.2009.04.008

Odden J et al (2018) Wolf attacks on dogs in Scandinavia - an interdisciplinary approach. NINA Report 1568 (In Norwegian with English summary)

Pay J (1938) Memories of a harehunter. Steensballe, Oslo (In Norwegian)

Peterson RO, Vucetich JA, Bump JM, Smith DW (2014) Trophic cascades in a multicausal world: Isle Royale and Yellowstone. Annual Review of Ecology, Evolution, and Systematics 45(45):325. https:// doi.org/10.1146/annurev-ecolsys-120213-091634

Pinheiro JC, Bates DJ, DebRoy SD, Sarkar D (2012) Nlme: linear and nonlinear mixed effects models. R package version 3:1-101

R Development Core Team (2018) R 3.5.2: A language and environment for statistical computing., 3.2.3 edn. R Foundation for Statistical Computing, Vienna, Austria

Ripple WJ, Beschta RL (2012a) Large predators limit herbivore densities in northern forest ecosystems. Eur J Wildl Res 58:733-742. https:// doi.org/10.1007/s10344-012-0623-5 
Ripple WJ, Beschta RL (2012b) Trophic cascades in Yellowstone: the first 15 years after wolf reintroduction. Biol Conserv 145:205213. https://doi.org/10.1016/j.biocon.2011.11.005

Ripple WJ et al (2014a) Status and ecological effects of the world's largest carnivores. Science 343:151. https://doi.org/10.1126/ science. 1241484

Ripple WJ, Beschta RL, Fortin JK, Robbins CT (2014b) Trophic cascades from wolves to grizzly bears in Yellowstone. J Anim Ecol 83: 223-233. https://doi.org/10.1111/1365-2656.12123

Skogen K, Krange O (2003) A wolf at the gate: the anti-carnivore alliance and the symbolic construction of community. Sociol Rural 43:309325. https://doi.org/10.1111/1467-9523.00247

Skogen K, Johannson M, Figari H, Flykt A, Krange O (2018) Experiences with wolves. NINA Report 1567 (In Norwegian)

Storaas T et al. (2008) Effects of wolves on moose: when the wolf came and went from Koppangkjølen. Hedmark University College Report 1-2008, Elverum (In Norwegian with English summary)

TNS Gallup (2017) Natur- og miljøbarometer 2017 - Nordmenns holdninger og atferd i natur- og miljøvernspørsmål. TNS Gallup (In Norwegian)

Treves A, Karanth KU (2003) Human-carnivore conflict and perspectives on carnivore management worldwide. Conserv Biol 17:14911499. https://doi.org/10.1111/j.1523-1739.2003.00059.x
Wabakken P, Sand H, Liberg O, Bjärvall A (2001) The recovery, distribution, and population dynamics of wolves on the Scandinavian peninsula, 1978-1998. Can J Zool 79:710-725. https://doi.org/10. 1139/z01-029

Wabakken P, Svensson L, Maartmann E, Åkesson M, Flagstad Ø (2016) Population monotoring of wolves winter 2015-2016. Population status of large carnivores in Scandinavia. Rovdata og Viltskadecenter, report 1-2016, SLU, Evenstad and Grimsö, (In Norwegian)

Wabakken P et al. (2017) Wolf depredation on livestock, semi-domestic reindeer and domestic dogs in Norway: history and potential of damage in relation to wolf dispersal patterns. Høgskolen i Innlandet Report 2-2017, Evenstad (In Norwegian with English summary)

Woodroffe R, Thirgood S, Rabinowitz A (2005) People and wildlife. Conflict or coexistance? Cambridge University Press, Cambridge

Publisher's note Springer Nature remains neutral with regard to jurisdictional claims in published maps and institutional affiliations. 